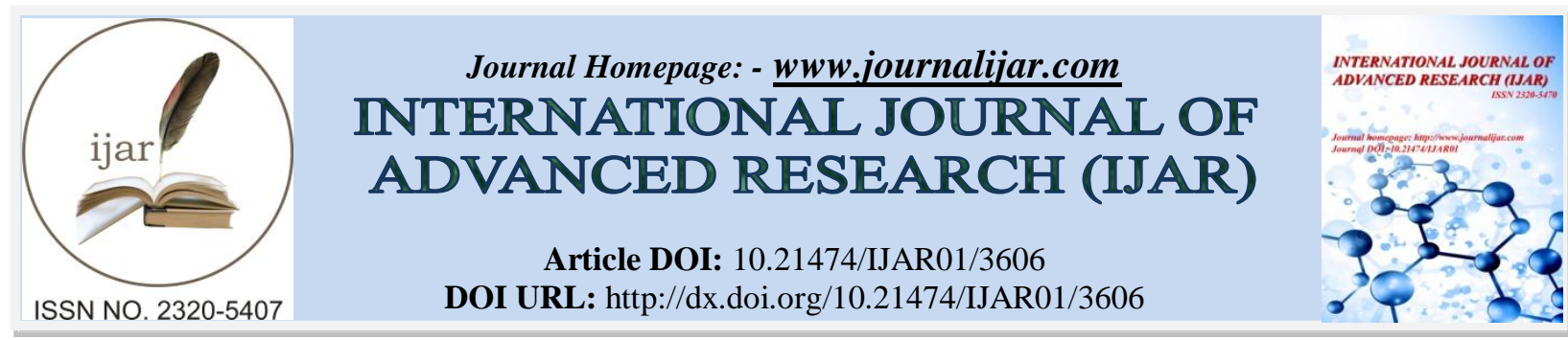

RESEARCH ARTICLE

\title{
HYDROGEOCHEMICAL STUDIES AND GROUNDWATER QUALITY EVALUATION IN HANUR WATERSHED, KOLLEGAL TALUK, CHAMARAJNAGAR DISTRICT, KARNATAKA STATE, SOUTH INDIA.
}

K. Siddaraju, D. Nagaraju, H. M. Bhanuprakash, H. M. Shivaswamy and A. Balasubramanian. Department of Studies in Earth Science, Manasagangotri, Mysuru, 570006 Karnataka, India.

\section{Manuscript Info}

Manuscript History

Received: 06 January 2017

Final Accepted: 06 February 2017

Published: March 2017

Key words:-

Groundwater, chemical characters,

Chemical classification, SAR, RSC,

USSL diagram.

\begin{abstract}
Groundwater is becoming a scant resource in part of Kollegal taluk, Chamarajnagar District, Karnataka State. This area receives an average annual rainfall of $696 \mathrm{~mm}$. Groundwater has been the major sources of irrigation and drinking purpose for several years almost 80 percent of area is underlain by hard rocks. The study area is drought prone, most of the people in this area depend on groundwater for drinking water and agriculture. Therefore, constant monitoring and assessment of water resource is necessary. The study area is bounded by Yelandur and T. Narasipura Taluk to the west, Mandya and Bangalore to the North, and East and South it is bounded by Dharamapuri District of TamilNadu this area is located in the south eastern corner of Karnataka. The area is located between $77^{0} 5^{1}$ to $77^{0} 30^{1}$ East longitude $11^{0} 45^{1}$ to $12^{0} 15^{1}$ North latitude with an areal extent of 1026sq km covering 138 villages coming under the Survey of India Toposheet (SOI) numbers are 57 $\mathrm{H} / 4,57 \mathrm{H} / 7,57 \mathrm{H} / 8,58 \mathrm{E} / 1$ and $58 \mathrm{E} / 5$. The study area comes under the semiarid region. In recent years, this region has been facing water scarcity as well as water quality problems. The major sources of employment are sericulture, agriculture and horticulture, engaging almost $70 \%$ of the workforce. Water samples have been collected from 68 locations of the study area, during the monsoon year 2016, The collected samples were analysed for chemical parameters. In the study area $\mathrm{Ca}-\mathrm{Mg}-\mathrm{HCO} 3$ type of water predominates during the mansoon season of year 2016. On the basis of hydro-chemical facies classification the water is found to be suitable for irrigation. The other evaluated parameters are SAR, RSC, salinity sodium hazard and USSL Classification.
\end{abstract}

Copy Right, IJAR, 2017,. All rights reserved.

\section{Introduction:-}

Water is the most important commodity for all living things, in rural as well as urban areas Because of increase, in agricultural and domestic activities, the demand is increasing. Quantity of water without quality is of no utility and hence chemical quality of water has gained equal importance along with quantity. The quality of any water may be altered due to over usage of fertilizers and other biogenic activity. The chemistry of host rock through which the groundwater flows below the earth surface and the total time of residence of the water with the host material control the chemistry of groundwater. The present study aims to obtain comprehensive information on the quality of 
groundwater of Hanur Watershed which lies on South Eastern parts of Kollegal Taluk, Chamarajnagar District, Karnataka state, India. The study area comes under Southern Dry Zone-VI Groundwater samples were collected and analyzed for determining its quality in the laboratory.

\section{Study Area:-}

Hanur Watershed of Kollegal taluk, Chamarajnagar District is located in the south eastern corner part of Karnataka state between $77^{0} 5^{1}$ to $77^{0} 30^{1}$ East longitude $11^{0} 45^{1}$ to $12^{0} 15^{1}$ North latitude (Figure 1). It covers an area of 1026 sq.km. Groundwater is influenced by underlaying lithology, structures, soil types thickness and structure of rock formations. Weathered and fractured charnokites, hornblende/ampibolite schist form the main aquifer in Hanur watershed. Groundwater in the study area occurs under water table conditions in the weathered and fractured charnokites, hornblende/ampibolite schist (Figure 2); there is no perennial river in the study area. Most of the people depend on groundwater resource for their domestic and agricultural requirements, the major ion chemistry of groundwater of Hanur watershed has not been studied earlier. During the monsoon period in the year 2016, 68 Samples were collected from the different locations of the study area. The collected water samples were transferred into precleaned polythene container for analysis of chemical characters. Chemical analyses were carried out for the major ion concentrations of the water samples collected from different locations using the standard procedures recommended by APHA-1994. The analytical data has been used for the classification of water for utilitarian purposes and for ascertaining various factors on which the chemical characteristics of water depend.

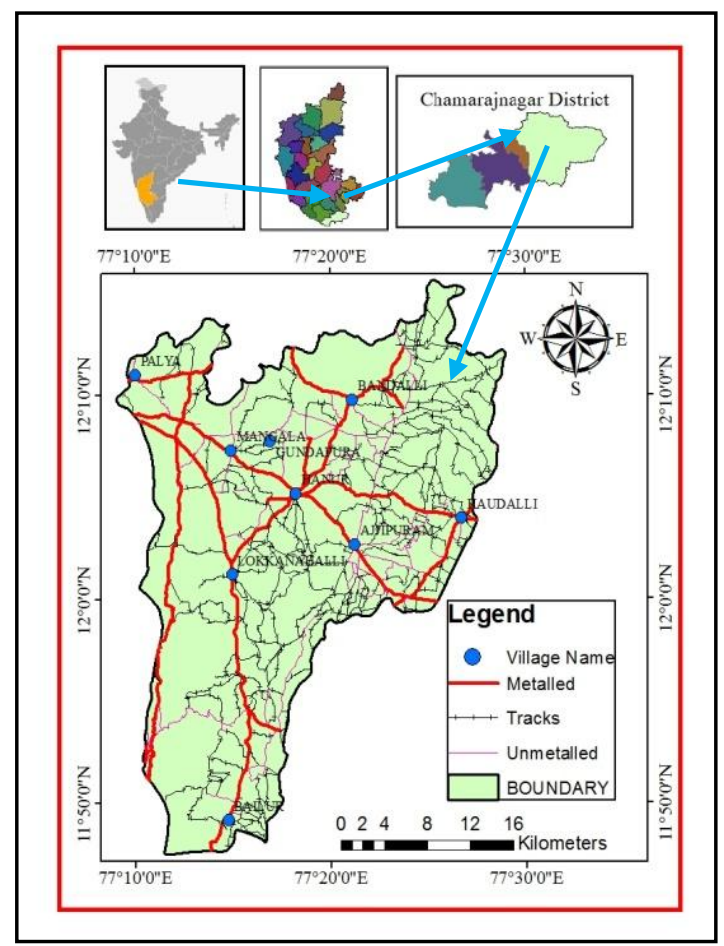

Figure 1:- Location map of the study area. 


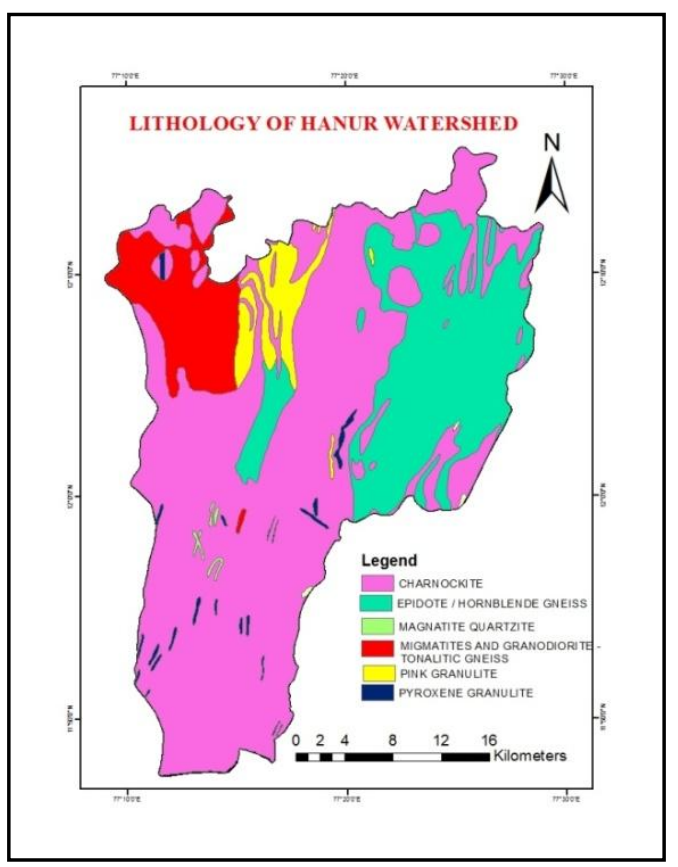

Figure 2:- Lithology of Study area.

\section{Methodology:-}

As stated earlier, 68 locations Groundwater samples were collected from Hanur watershed during monsoon period 2016 (Figure 3). The collected water samples were stored in pre-treated polythene bottles and transferred laboratory for analysis of major chemical elements - $\mathrm{Ca}^{+2}, \mathrm{Mg}^{+2}, \mathrm{Cl}^{-1}, \mathrm{HCO}_{3}^{-1} \mathrm{Na}^{+1}, \mathrm{~K}^{+1}$, and $\mathrm{SO}_{4}^{-2}$. Using the standard procedures recommended by APHA-1994.

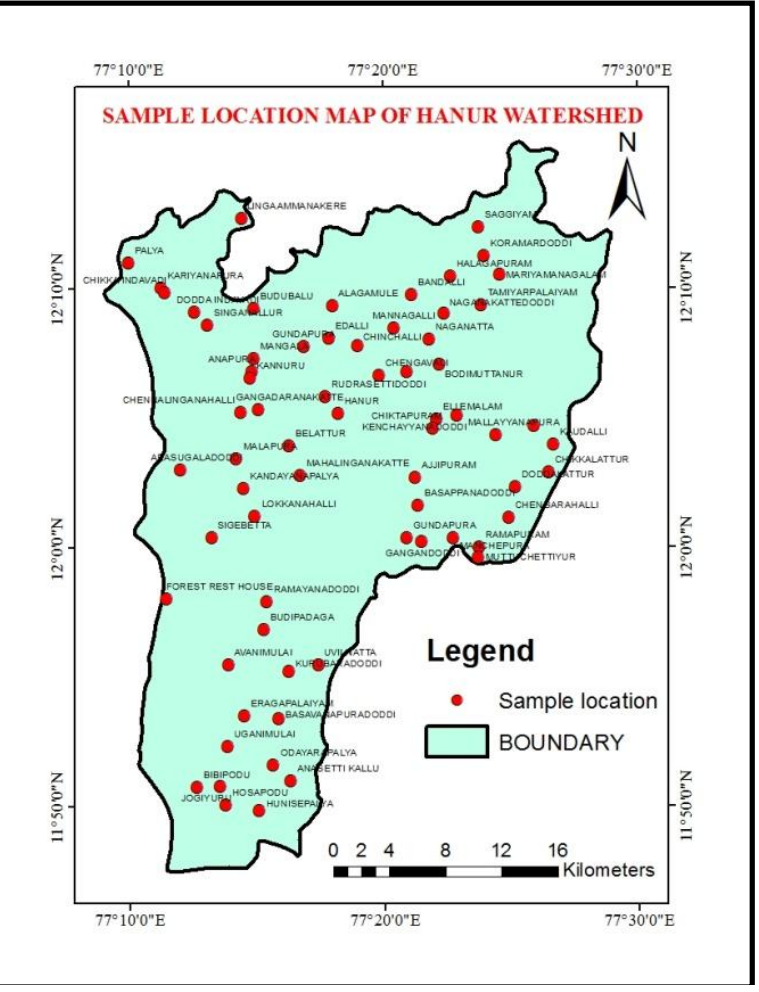

Figure 3:- Sample Location of study area 


\section{Results and Discussion:-}

The Groundwater quality reveals that the $\mathrm{pH}$ varies from 6.28 to 9.4, EC ranges from 86 to $2670 \mu \mathrm{mho} / \mathrm{cm}$, total dissolved solids(TDS) values range from 385 to $1926 \mathrm{mg} / \mathrm{l}$, calcium varies from 20 to $179 \mathrm{mg} / \mathrm{l}, \mathrm{Mg}$ varies from 14 to $109 \mathrm{mg} / \mathrm{l}, \mathrm{Na}+\mathrm{k}$ varies from 21 to $546 \mathrm{mg} / \mathrm{l}, \mathrm{Cl}$ values range from 14 to $376 \mathrm{mg} / \mathrm{l}, \mathrm{Co} 3$ values range from 0 to 93 $\mathrm{mg} / \mathrm{l}, \mathrm{HCO} 3$ values range from 152 to $646 \mathrm{mg} / \mathrm{l}$, SO4 values range from 0.5 to $552 \mathrm{mg} / \mathrm{l}$, NO3 values range from 0 to $62 \mathrm{mg} / \mathrm{l}$ in water of the study area. Chemical data of water samples are given in Table 1 . Year -2016

Table 1:- Different chemical parameters of Hanur watershed -2016 (PPM)

\begin{tabular}{|c|c|c|c|c|c|c|c|c|c|c|c|}
\hline SI no & TDS & EC & Ca & Mg & $\mathrm{Na}+\mathrm{K}$ & HCO3 & $\mathrm{CO3}$ & Cl & NO3 & SO4 & pH \\
\hline 1 & 795 & 1220 & 165.0 & 73.0 & 98.0 & 530.0 & 10.0 & 230.0 & 62.0 & 89.0 & 7.09 \\
\hline 2 & 786 & 1200 & 162.0 & 75.0 & 92.0 & 526.0 & 10.0 & 234.0 & 1.0 & 1.6 & 7.06 \\
\hline 3 & 480 & 733 & 33.6 & 47.0 & 66.5 & 310.0 & 10.0 & 88.0 & 0.2 & 0.6 & 8.1 \\
\hline 4 & 478 & 730 & 20.0 & 38.0 & 57.0 & 300.0 & 10.0 & 40.0 & 0.5 & 13.8 & 7.65 \\
\hline 5 & 485 & 736 & 22.0 & 42.0 & 62.0 & 320.0 & 10.0 & 52.0 & 0.4 & 14.0 & 7.68 \\
\hline 6 & 500 & 740 & 22.0 & 42.0 & 63.0 & 294.0 & 10.0 & 63.0 & 0.8 & 22.8 & 7.72 \\
\hline 7 & 490 & 746 & 21.0 & 37.0 & 58.0 & 264.0 & 10.0 & 55.0 & 10.0 & 15.6 & 7.75 \\
\hline 8 & 680 & 860 & 69.0 & 42.0 & 86.0 & 450.0 & 35.0 & 58.0 & 7.0 & 20.0 & 7.6 \\
\hline 9 & 700 & 1020 & 160.0 & 75.0 & 62.0 & 486.0 & 10.0 & 198.0 & 18.8 & 75.4 & 6.85 \\
\hline 10 & 810 & 1185 & 157.0 & 71.0 & 62.0 & 505.7 & 10.0 & 210.0 & 14.5 & 81.8 & 6.28 \\
\hline 11 & 495 & 650 & 56.0 & 33.0 & 90.0 & 436.4 & 24.0 & 42.0 & 2.6 & 12.0 & 8.6 \\
\hline 12 & 838 & 2320 & 16.0 & 68.0 & 465.0 & 646.0 & 42.0 & 322.0 & 12.0 & 225.0 & 7.25 \\
\hline 13 & 760 & 1100 & 32.0 & 38.0 & 266.0 & 520.0 & 36.0 & 204.0 & 22.0 & 28.0 & 7.02 \\
\hline 14 & 554 & 2050 & 50.0 & 36.0 & 186.0 & 486.0 & 10.0 & 143.0 & 14.2 & 16.8 & 7.36 \\
\hline 15 & 618 & 642 & 62.0 & 28.0 & 126.0 & 455.0 & 50.0 & 34.0 & 18.0 & 26.0 & 7.8 \\
\hline 16 & 834 & 1516 & 50.0 & 69.0 & 160.0 & 484.0 & 40.0 & 138.0 & 25.0 & 94.0 & 7.78 \\
\hline 17 & 615 & 86 & 60.0 & 28.0 & 126.0 & 340.0 & 38.0 & 66.0 & 16.0 & 54.0 & 8.32 \\
\hline 18 & 250 & 380 & 34.0 & 15.0 & 40.0 & 152.0 & 43.0 & 17.0 & 10.0 & 10.0 & 8.7 \\
\hline 19 & 400 & 826 & 44.0 & 24.0 & 71.0 & 280.0 & 45.0 & 22.0 & 13.0 & 22.6 & 8.6 \\
\hline 20 & 447 & 596 & 42.0 & 25.0 & 84.0 & 316.0 & 50.0 & 30.0 & 10.0 & 0.5 & 8.56 \\
\hline 21 & 640 & 978 & 80.0 & 35.0 & 74.0 & 295.0 & 44.0 & 96.0 & 16.0 & 42.0 & 7.82 \\
\hline 22 & 1136 & 1016 & 90.0 & 97.0 & 312.0 & 712.0 & 10.0 & 86.0 & 14.0 & 552.0 & 7.76 \\
\hline 23 & 580 & 628 & 60.0 & 25.0 & 84.0 & 378.0 & 48.0 & 14.0 & 15.0 & 16.0 & 7.82 \\
\hline 24 & 725 & 610 & 48.0 & 30.0 & 112.0 & 318.0 & 35.0 & 54.0 & 16.0 & 48.0 & 7.8 \\
\hline 25 & 552 & 884 & 28.0 & 35.6 & 138.0 & 398.6 & 54.4 & 38.2 & 3.4 & 24.0 & 7.4 \\
\hline 26 & 518 & 860 & 44.0 & 47.0 & 136.0 & 390.0 & 72.0 & 50.0 & 16.0 & 78.0 & 8.2 \\
\hline 27 & 442 & 820 & 38.0 & 62.0 & 99.0 & 420.0 & 40.0 & 62.0 & 8.2 & 62.0 & 7.6 \\
\hline 28 & 600 & 830 & 45.0 & 43.0 & 260.0 & 573.0 & 72.0 & 76.0 & 12.0 & 120.0 & 8.3 \\
\hline 29 & 1082 & 1020 & 71.0 & 33.0 & 101.0 & 442.0 & 0.0 & 54.0 & 15.2 & 82.0 & 8.4 \\
\hline 30 & 858 & 984 & 61.0 & 29.0 & 99.0 & 360.0 & 28.0 & 37.0 & 13.2 & 86.0 & 8 \\
\hline 31 & 718 & 480 & 44.0 & 42.0 & 111.0 & 432.0 & 36.0 & 49.0 & 10.0 & 38.0 & 8.2 \\
\hline 32 & 624 & 782 & 48.0 & 30.0 & 144.0 & 434.0 & 58.0 & 46.0 & 10.0 & 32.0 & 7.72 \\
\hline 33 & 496 & 548 & 58.0 & 34.0 & 90.0 & 435.0 & 26.0 & 44.0 & 3.8 & 14.0 & 8.48 \\
\hline 34 & 510 & 992 & 62.0 & 82.0 & 101.0 & 588.0 & 46.0 & 70.0 & 14.2 & 45.0 & 7.8 \\
\hline 35 & 420 & 834 & 48.0 & 58.0 & 72.0 & 410.0 & 34.0 & 58.0 & 6.4 & 36.0 & 7.62 \\
\hline 36 & 518 & 712 & 56.0 & 34.0 & 80.0 & 395.0 & 46.0 & 16.0 & 18.0 & 16.0 & 8.08 \\
\hline 37 & 560 & 860 & 46.0 & 48.0 & 100.0 & 355.0 & 43.0 & 40.0 & 14.0 & 80.0 & 8.7 \\
\hline 38 & 775 & 1200 & 61.0 & 48.0 & 145.0 & 196.0 & 24.0 & 216.0 & 14.0 & 100.0 & 7.97 \\
\hline 39 & 324 & 566 & 58.0 & 16.0 & 45.0 & 214.0 & 26.0 & 22.0 & 14.0 & 20.0 & 7.6 \\
\hline 40 & 808 & 1040 & 140.0 & 16.0 & 124.0 & 438.0 & 50.0 & 110.0 & 16.0 & 52.0 & 7.92 \\
\hline 41 & 1926 & 2080 & 46.0 & 68.0 & 546.0 & 905.0 & 93.0 & 205.0 & 14.0 & 342.0 & 7.8 \\
\hline 42 & 520 & 840 & 69.0 & 28.0 & 78.0 & 328.0 & 48.0 & 59.0 & 13.0 & 20.0 & 8.43 \\
\hline 43 & 528 & 995 & 30.0 & 48.6 & 72.0 & 328.4 & 33.8 & 47.8 & 10.0 & 30.0 & 9.4 \\
\hline 44 & 560 & 1000 & 126.0 & 37.0 & 50.0 & 421.0 & 29.0 & 78.0 & 15.0 & 50.0 & 7.66 \\
\hline 45 & 642 & 998 & 54.0 & 43.0 & 98.0 & 310.0 & 50.0 & 96.0 & 16.0 & 45.0 & 8.8 \\
\hline 46 & 600 & 782 & 62.0 & 36.0 & 112.0 & 408.0 & 54.0 & 28.0 & 34.0 & 30.0 & 8.5 \\
\hline
\end{tabular}




\begin{tabular}{|c|c|c|c|c|c|c|c|c|c|c|c|}
\hline 47 & 618 & 1018 & 48.0 & 79.0 & 50.0 & 437.0 & 43.6 & 60.0 & 12.0 & 24.6 & 8 \\
\hline 48 & 676 & 812 & 75.0 & 40.0 & 105.0 & 478.0 & 40.0 & 50.0 & 18.0 & 10.0 & 7.62 \\
\hline 49 & 576 & 912 & 86.0 & 43.0 & 115.0 & 578.0 & 44.0 & 52.0 & 19.0 & 10.0 & 8.15 \\
\hline 50 & 680 & 1250 & 135.0 & 42.0 & 48.0 & 433.0 & 52.0 & 85.0 & 21.0 & 50.0 & 7.15 \\
\hline 51 & 635 & 1215 & 129.0 & 38.0 & 51.5 & 415.0 & 25.0 & 78.0 & 35.0 & 47.0 & 7.69 \\
\hline 52 & 598 & 896 & 43.0 & 28.0 & 110.8 & 192.0 & 0.0 & 188.0 & 1.4 & 56.0 & 7 \\
\hline 53 & 605 & 1100 & 128.0 & 38.0 & 51.0 & 425.0 & 30.0 & 80.0 & 41.0 & 52.0 & 7.56 \\
\hline 54 & 825 & 1050 & 140.0 & 14.0 & 126.1 & 437.0 & 48.0 & 110.0 & 40.0 & 50.0 & 7.79 \\
\hline 55 & 721 & 910 & 48.0 & 31.0 & 122.0 & 205.0 & 0.0 & 201.0 & 1.8 & 61.0 & 7.5 \\
\hline 56 & 545 & 710 & 30.0 & 41.0 & 97.0 & 450.0 & 0.0 & 30.0 & 30.0 & 21.0 & 8.5 \\
\hline 57 & 1010 & 1700 & 158.0 & 30.0 & 163.6 & 470.0 & 78.0 & 172.0 & 56.0 & 67.0 & 8.5 \\
\hline 58 & 545 & 715 & 53.0 & 47.0 & 96.0 & 400.0 & 48.0 & 38.0 & 31.0 & 22.0 & 8.5 \\
\hline 59 & 889 & 1453 & 88.0 & 57.0 & 73.0 & 428.0 & 0.0 & 116.0 & 25.6 & 78.0 & 6.7 \\
\hline 60 & 1838 & 2670 & 179.0 & 109.0 & 116.0 & 544.0 & 0.0 & 376.0 & 4.7 & 164.0 & 7.1 \\
\hline 61 & 410 & 510 & 35.0 & 21.0 & 76.0 & 260.0 & 35.0 & 19.0 & 14.0 & 17.0 & 7.93 \\
\hline 62 & 385 & 635 & 44.0 & 27.0 & 76.0 & 268.0 & 6.0 & 30.0 & 58.0 & 55.0 & 8.43 \\
\hline 63 & 710 & 535 & 36.0 & 33.0 & 73.0 & 275.0 & 14.0 & 33.0 & 59.0 & 44.0 & 7.4 \\
\hline 64 & 690 & 875 & 71.0 & 40.0 & 106.0 & 480.0 & 40.0 & 50.0 & 9.0 & 12.0 & 7.61 \\
\hline 65 & 720 & 1150 & 45.0 & 41.0 & 30.0 & 335.0 & 0.0 & 51.0 & 0.2 & 2.1 & 7.4 \\
\hline 66 & 650 & 1200 & 35.0 & 31.0 & 21.0 & 210.0 & 0.0 & 52.0 & 5.0 & 14.0 & 7 \\
\hline 67 & 733 & 1100 & 70.0 & 52.0 & 33.0 & 410.0 & 0.0 & 50.0 & 55.0 & 12.0 & 7 \\
\hline 68 & 644 & 981 & 98.0 & 28.0 & 53.0 & 333.0 & 62.0 & 71.0 & 0.0 & 3.0 & 7.1 \\
\hline
\end{tabular}

Total Dissolved Solids:-

As groundwater moves and stays for a longer time along its flow path, increased in total dissolved concentrations and major ions normally occur (Norris et al. 1992). Higher TDS shows longer residence period of water (Davis and De Viest, 1966). TDS content is usually the main factor, which limits or determines the use of groundwater for any purpose (Nordstrom, 1987). The analysis of samples for the seasons has shown that there is a general tendency of increase of TDS, based on TDS, for various uses like general household, drinking, irrigation and understanding and it could be seen from the (table.1) that a majority of the portion is occupied by 500 to $1000 \mathrm{ppm}$ TDS followed by $<500 \mathrm{ppm}$ concentration and finally $>1000 \mathrm{ppm}$. During the stay or movement of the groundwater in the subsurface the TDS concentration slowly gets enriched and shown in figure 4. 


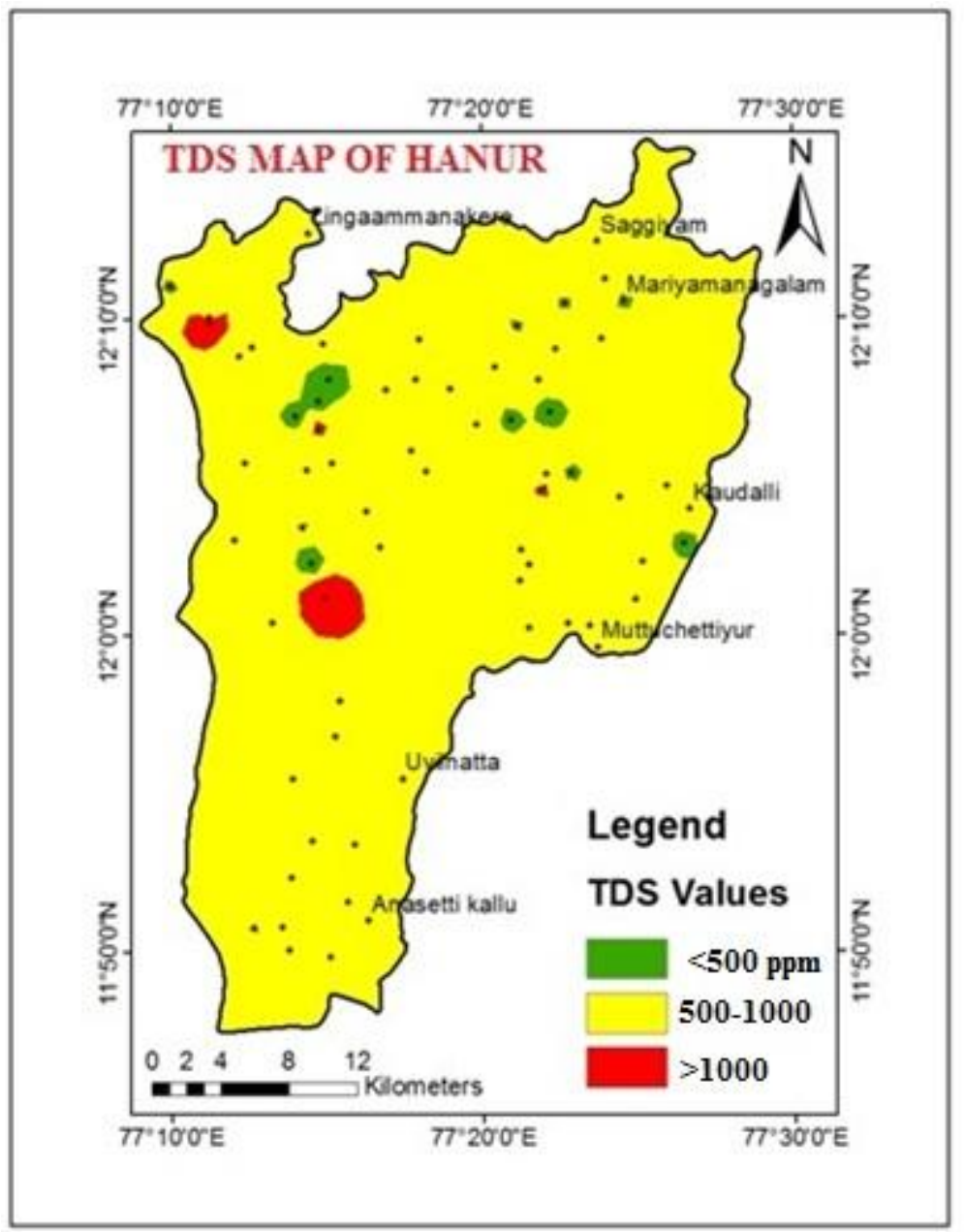

Figure 4:- Total dissolved solids of study area.

\section{Hydrochemistry of Groundwater:-}

Piper $(1944,1953)$ introduced a trilinear diagram which is used to evaluate the geochemical evolution of groundwater and relationship between rock type and water composition. Analysis of piper's trilinear plot shows that most of ground water samples are of Ca-Mg $-\mathrm{HCO}_{3}$ type (Figure 5).

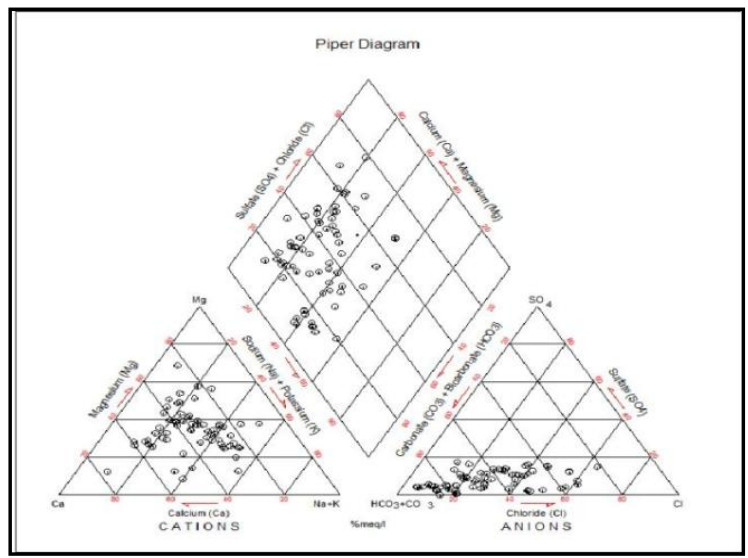

Figure 5:- Plotted in piper-Trilinear diagram. 


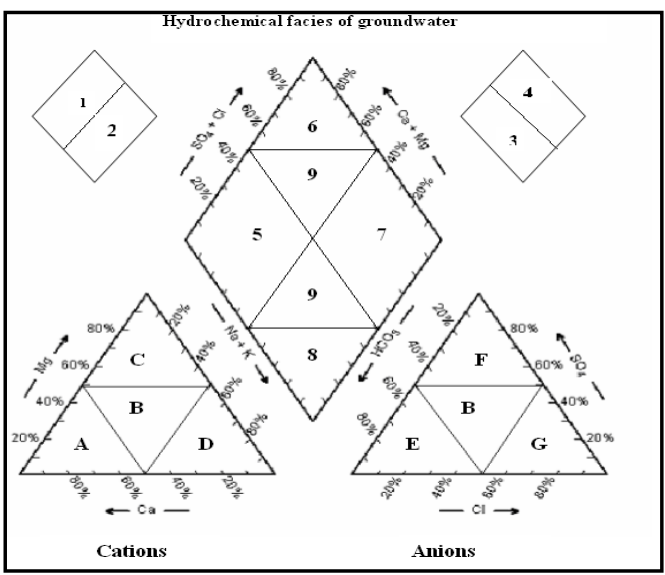

Figure 6:- Classification diagram for anion and cation facies in the form of major -ion percentages. Water types are designed according to domain in which they occur on the diagram segments.

Legend:-

A- Calcium type, B- No Dominant type,

C- Magnesium type, D- Sodium and potassium type

E- Bicarbonate type, F- Sulphate type,

G- Chloride type

Hydrochemical facies are distinct zones that projects the dominating cation and anion concentration in water. To define the composition class, Back and co-workers suggested various sub divisions within the tri-linear diagram (Figure 5). The interpretation of distinct facies from the 0 to $10 \%$ and 90 to $100 \%$ domains, on the diamond shaped cation to anion graph, is more helpful than using equal $25 \%$ increments. It clearly explains the variations or domination of cation and anion concentrations. Groundwater Hardness is important parameters for water use and consumption. Hardness is caused primarily due to the presence of cations such as calcium and magnesium and anions such as carbonate, bicarbonate, chloride and sulfate in water. Wilcox classified groundwater for irrigation purposes based on \% sodium and electrical conductivity. Eaton recommended the concentration of Residual Sodium Carbonate to determine the suitability of water for irrigation purposes. The US-Salinity Laboratory of the Department of Agriculture adopted certain techniques based on which the suitability of water for agriculture is explained. The sodium in irrigation waters is usually denoted as per cent sodium and can be determined using the following formula.

$$
\% \mathrm{Na}=(\mathrm{Na}+) \times 100 /\left(\mathrm{Ca}^{2}++\mathrm{Mg}^{2}++\mathrm{Na}^{+1}+\mathrm{K}^{+1}\right)
$$

That is the quantities of $\mathrm{Ca}^{2+,} \mathrm{Mg}^{2+} \mathrm{Na}^{+}$and $\mathrm{K}^{+}$are expressed in milliequivalents per liter (epm).

Table 2:- Classification of water based on \% sodium

\begin{tabular}{|l|c|c|c|c|}
\hline$\%$ Na & $\begin{array}{c}\text { Water } \\
\text { Class }\end{array}$ & $\begin{array}{c}\text { No. } \\
\text { Samples }\end{array}$ & $\mathbf{\%}$ & Sample Nos \\
\hline Up to 20 & Excellent & 10 & 14.70 & $9,10,44,47,50,51,53,65,66,67$ \\
\hline $20-40$ & Good & 24 & 35.30 & $1,2,3,4,5,6,7,8,18,21,27,34,35,36,39,40,42,43,48,49,58,59,60,68$ \\
\hline $40-60$ & Permissible & 30 & 44.12 & $11,14,15,16,17,19$, \\
& & & & $20,22,23,24,25,26,29,30,31,32,33,37,38,45,46,52,54,55,56,57,61,62,63,64$. \\
\hline $60-80$ & Doubtful & 4 & 5.88 & $12,13,28,41$ \\
\hline \multicolumn{7}{|c|}{ Total } & $\mathbf{6 8}$ & $\mathbf{1 0 0}$ & \\
\hline
\end{tabular}




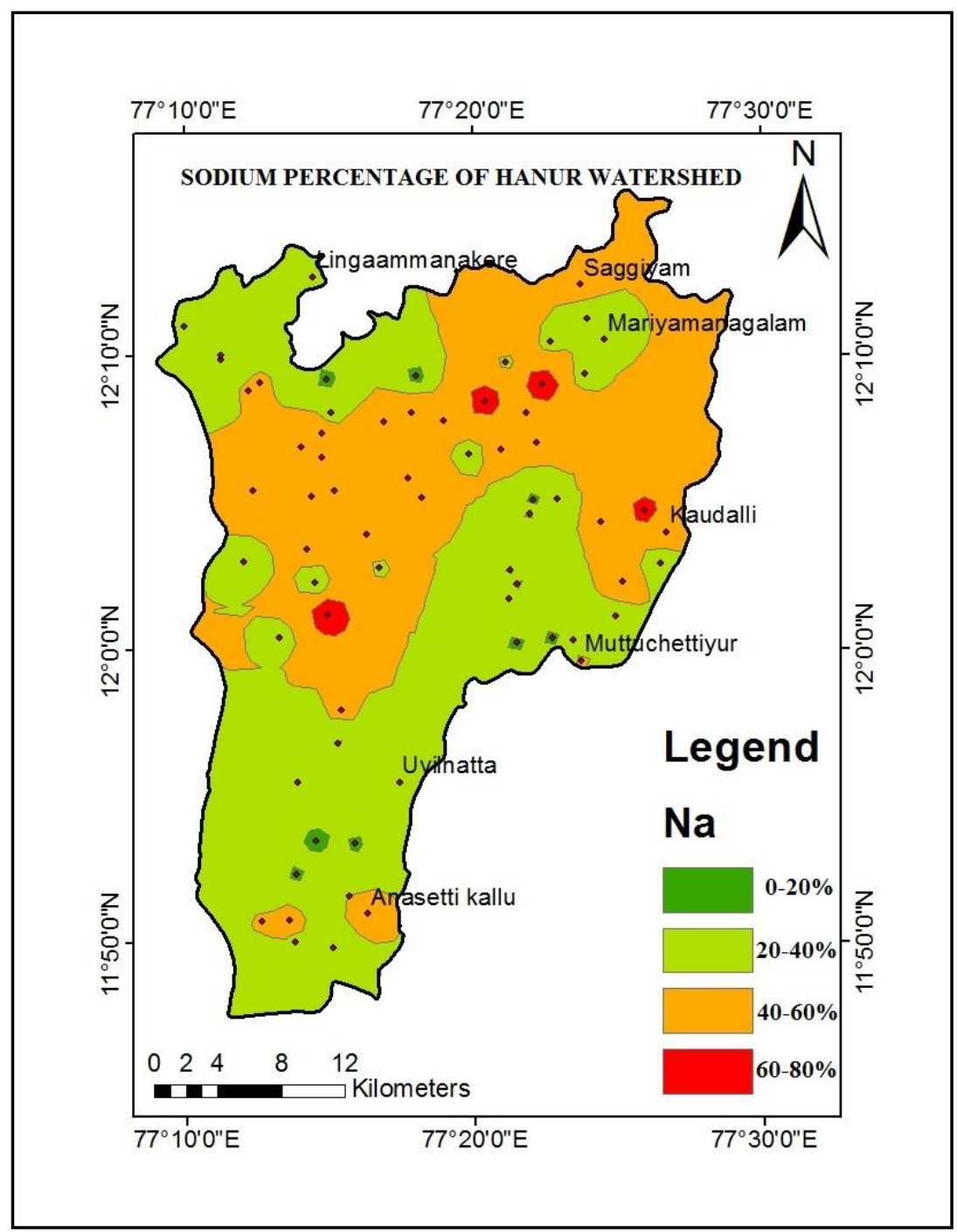

Figure.7 Sodium Percentage of the study area

Table 3:- Groundwater quality based on RSC (Residual Sodium Carbonate).

\begin{tabular}{|c|l|c|c|l|}
\hline $\begin{array}{c}\text { RSC } \\
\text { (epm) }\end{array}$ & Water Class & $\begin{array}{c}\text { No } \\
\text { Samples }\end{array}$ & \multicolumn{1}{|c|}{ Sample Nos } & \multicolumn{1}{c|}{} \\
\hline$<1.25$ & Good & 26 & 38.24 & $\begin{array}{l}3,4,5,6,7,16,18,21,22,27,29,35,37,39,40,42,43,45,47,54,62,63,65,66,67, \\
68 .\end{array}$ \\
\hline $\begin{array}{c}1.25- \\
2.5\end{array}$ & Doubtful & 22 & 32.35 & $8,11,17,19,24,30,33,34,36,44,46,48,50,51,52,53,55,56,58,59,61,64$. \\
\hline$>2.5$ & Unsuitable & 20 & 29.41 & $1,2,9,10,12,13,14,15,20,23,25,26,28,31,32,38,41,49,57,60$. \\
\hline \multicolumn{2}{|c|}{} & $\mathbf{6 8}$ & $\mathbf{1 0 0}$ & \\
\hline
\end{tabular}

The classification of groundwater samples with respect to per cent sodium is shown in (Table 2). It is observed that about 10 samples are excellent, 24 samples are good, 30 samples are permissible in this limit and 4 samples are doubtful. In waters having high concentration of bicarbonate, there is tendency for calcium and magnesium to precipitate as the water in the soil becomes more concentrated. As a result, the relative proportion of sodium in the water is increased in the form of sodium carbonate. RSC is calculated using the following equation.

$$
\mathbf{R S C}=\left(\mathrm{HCO}_{3^{-}}+\mathrm{CO}_{3}{ }^{2-}\right)-\left(\mathrm{Ca}^{2}++\mathbf{M g}^{2+}\right)
$$

That is all ionic concentrations are expressed in epm. 


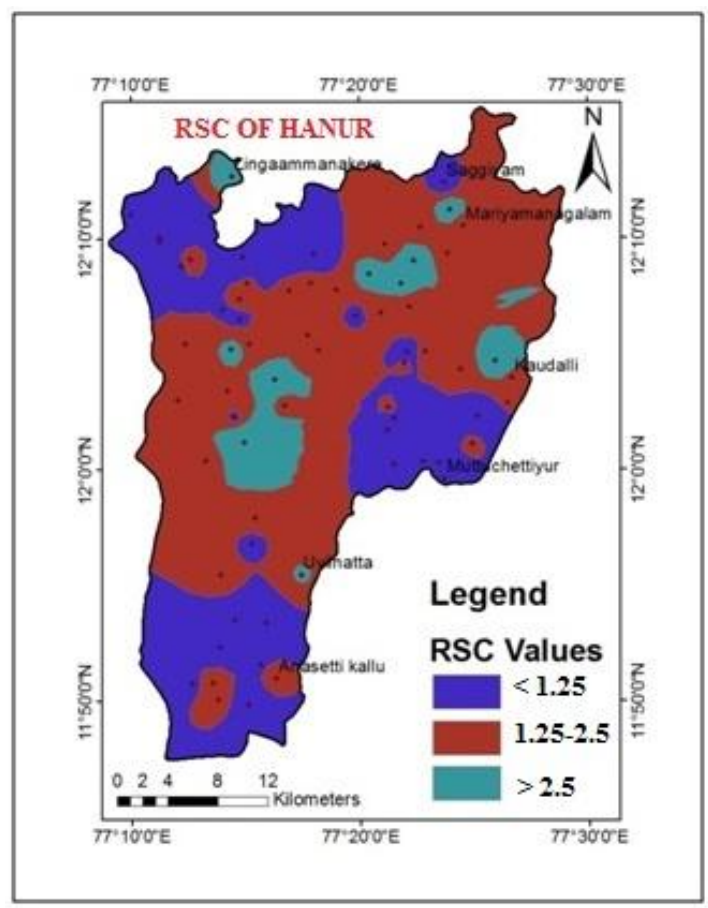

Figure 8:- Residual Sodium corbonate of the study area.

According to the US Department of Agriculture, water having more than $2.5 \mathrm{epm}$ of RSC is not suitable for irrigation purposes. Groundwater of the study area is classified on the basis of RSC and the results are presented in (Table.3). Based on RSC values, out of 68 samples, 8 samples have shown values less than 1.25 and are safe for irrigation.

The most important characteristics of irrigation water in determining its quality are: (i) Total concentration of soluble salts; (ii) Relative proportion of sodium to other principal cations; (iii) Concentration of boron or other element that may be toxic, and (iv) Under some condition, bicarbonate concentration as related to the concentration of calcium plus magnesium. These have been termed as the salinity hazard, sodium hazard, boron hazard and bicarbonate hazard. In the past, the sodium hazard has been expressed as per cent sodium of total cations. A better measure of the sodium hazard for irrigation is the SAR which is used to express reactions with the soil. SAR is computed as where all ionic concentrations are expressed in epm.

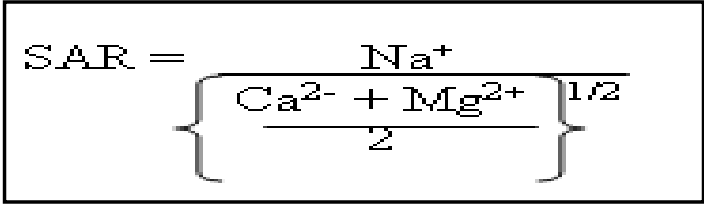

Table 4:- Classification of Sodium Adsorption Ratio.

\begin{tabular}{|c|c|c|c|c|}
\hline SAR & $\begin{array}{l}\text { Water } \\
\text { class }\end{array}$ & $\begin{array}{c}\text { No. of } \\
\text { Samples }\end{array}$ & $\%$ & Sample Nos \\
\hline$<1$ & Excellent & 4 & 5.88 & $50,65,66,67$ \\
\hline$>1$ & Good & 64 & 94.12 & $\begin{array}{l}1,2,3,4,5,6,7,8,9,10,11,12,13,14,15,16,17,18,19,20, \\
21,22,23,24,25,26,27,28,29,30,31,32,33,34,35,36,37,38,39,40,41,42,4 \\
3,44,45,46,47,48,49,51,52,53,54,55,56,57,58,59,60,61,62,63,64,68 .\end{array}$ \\
\hline & Total & 68 & 100 & \\
\hline
\end{tabular}




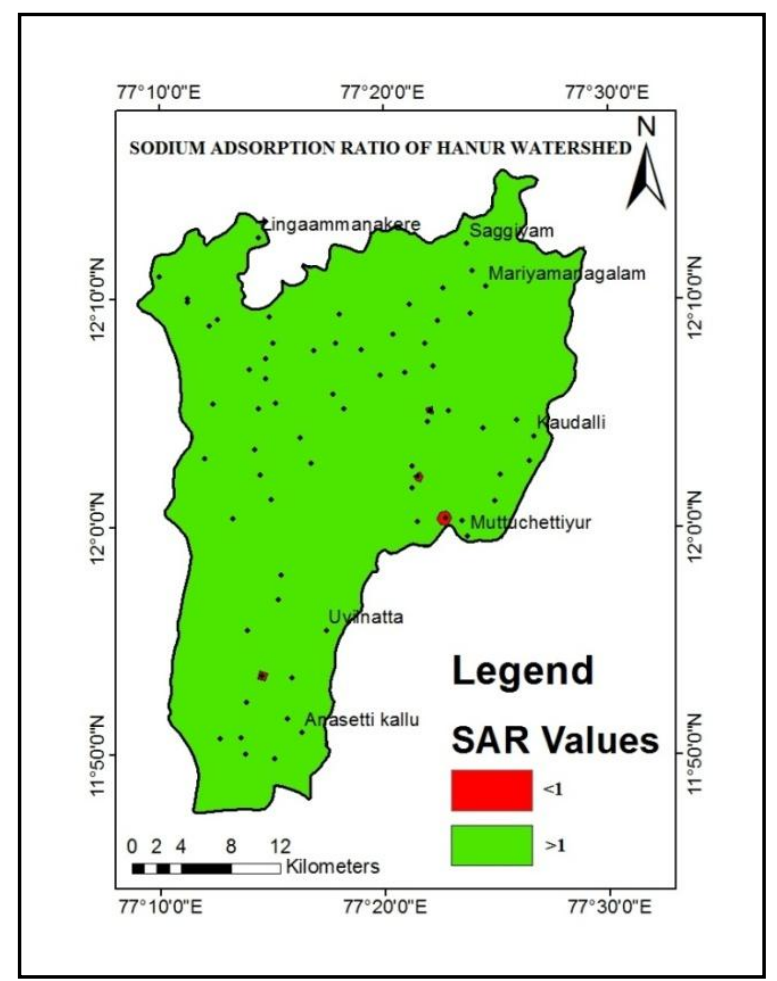

Figure 9:- Sodium Adsorption of the study area.

The classification of groundwater samples from the study area with respect to SAR is represented in (Table 4). The SAR value of all the samples are found to be less than 6 , and are classified as excellent for irrigation. When the SAR and specific conductance of water are known, the classification of water for irrigation can be determined by graphically plotting these values on the US salinity (USSL) diagram (Figures 10\&11). The groundwater of Hanur watershed is in general $\mathrm{Ca}-\mathrm{Mg}-\mathrm{HCO} 3$ type during year 2016. About $88.24 \%$ of the samples are grouped within $\mathrm{C} 2 \mathrm{~S} 1$ and $\mathrm{C} 3 \mathrm{~S} 1$ classes.

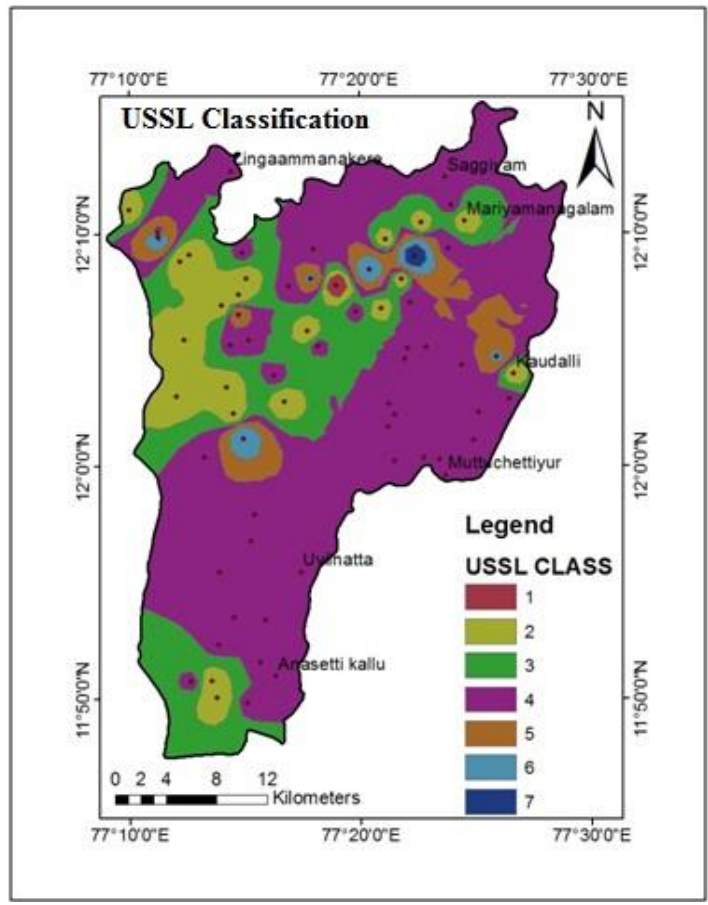

Figure 10:- Salinity Sodium hazard of study area. 
Table 5:- Stastical data of Salinity Sodium hazard (USSL Classification)

\begin{tabular}{|c|c|c|c|}
\hline Rank & Quality Parameter & No. of Samples & Percentage \\
\hline 1 & $\mathrm{C}_{1} \mathrm{~S}_{1}$ & 1 & 1.47 \\
\hline 2 & $\mathrm{C}_{2} \mathrm{~S}_{1}$ & 21 & 30.88 \\
\hline 3 & $\mathrm{C}_{3} \mathrm{~S}_{1}$ & 39 & 57.36 \\
\hline 4 & $\mathrm{C}_{3} \mathrm{~S}_{2}$ & 4 & 5.88 \\
\hline 5 & $\mathrm{C}_{3} \mathrm{~S}_{3}$ & 1 & 1.47 \\
\hline 6 & $\mathrm{C}_{4} \mathrm{~S}_{1}$ & 1 & 1.47 \\
\hline 7 & $\mathrm{C}_{4} \mathrm{~S}_{3}$ & 1 & 1.47 \\
\hline
\end{tabular}

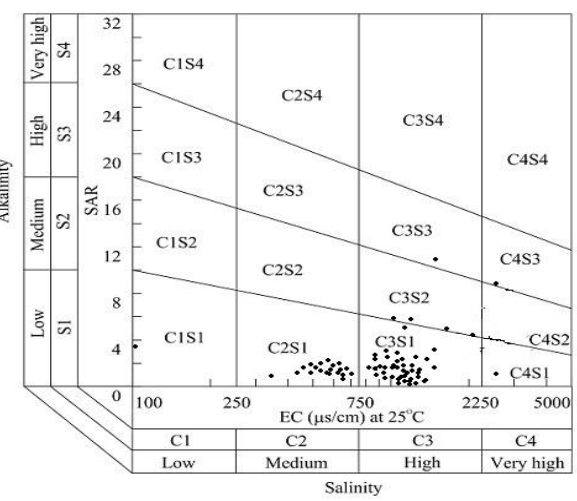

Plot of the SAR versus EC (USSL 1954).

Figure 11:- USSL classification of water samples.

For the purpose of diagnosis and classification, the total concentration of soluble salts (salinity hazard) in irrigation water can be expressed in terms of specific conductance. Classification of groundwater based on salinity hazard is presented in Table 5. It is found from the EC value; only 2 samples are found to be unsuitable for irrigation purposes. Table 5 shows the Salinity hazard classes. In the study area, the groundwater is generally $\mathrm{Ca}-\mathrm{Mg}_{-} \mathrm{HCO}$ type, which is mainly due to the geology of the area which comprises igneous rocks of crystalline nature, in which the major units are Charnokites and hornblende schist. Groundwater in the study area occurs under water table conditions in the weathered and fractured Charnokites and hornblende schist.

Table 6:- Comparison of the quality parameters of groundwater of the study area with WHO and ISI standard for drinking purpose.

\begin{tabular}{|c|c|c|c|c|c|c|c|c|}
\hline \multirow{2}{*}{$\begin{array}{l}\text { S.N } \\
\text { o. }\end{array}$} & \multirow{2}{*}{$\begin{array}{l}\text { Water } \\
\text { Quality } \\
\text { Parameters }\end{array}$} & \multicolumn{2}{|c|}{ WHO (1984) } & \multicolumn{2}{|c|}{ ISI (1991) } & \multirow[b]{2}{*}{$\begin{array}{l}\text { No. of locations } \\
\text { which exceed } \\
\text { max. } \\
\text { permissible } \\
\text { limit (WHO ) }\end{array}$} & \multirow[b]{2}{*}{$\begin{array}{l}\text { Concen } \\
\text { tration } \\
\text { in } \\
\text { Study } \\
\text { Area } \\
\end{array}$} & \multirow{2}{*}{$\begin{array}{l}\text { Undesirable Effect } \\
\text { Produced Beyond } \\
\text { Maximum Allowable } \\
\text { Limit }\end{array}$} \\
\hline & & $\begin{array}{l}\text { Max } \\
\text { Desirable }\end{array}$ & $\begin{array}{l}\text { Max. } \\
\text { Permissib } \\
\text { le }\end{array}$ & $\begin{array}{l}\text { Max. } \\
\text { Desir } \\
\text { able }\end{array}$ & $\begin{array}{l}\text { Max. } \\
\text { Permissi } \\
\text { ble }\end{array}$ & & & \\
\hline 1. & $\mathrm{pH}$ & 7.0 to 8.5 & 6.5 to 9.2 & $\begin{array}{l}6.5 \text { to } \\
8.5\end{array}$ & $\begin{array}{l}\text { No } \\
\text { relaxatio } \\
\mathrm{n}\end{array}$ & 1 & $\begin{array}{l}6.28 \text { to } \\
9.4\end{array}$ & $\begin{array}{l}\text { Taste, effects mucus } \\
\text { memberane and water } \\
\text { supply system }\end{array}$ \\
\hline 2. & TDS mg/l & 500 & 1500 & 500 & 1000 & 2 & $\begin{array}{l}250 \text { to } \\
1926\end{array}$ & $\begin{array}{l}\text { Gastrointestinal } \\
\text { irritation }\end{array}$ \\
\hline 3. & $\mathrm{Ca} \mathrm{mg/l}$ & 75 & 200 & 75 & 200 & 0 & $\begin{array}{l}16 \text { to } \\
179\end{array}$ & $\begin{array}{l}\text { Encrustation in water } \\
\text { supply, scale formation }\end{array}$ \\
\hline 4. & $\mathrm{Mg} \mathrm{ml} / \mathrm{l}$ & 30 & 150 & 30 & 100 & 0 & $\begin{array}{l}14 \text { to } \\
109\end{array}$ & $\begin{array}{l}\text { Encrustation in water } \\
\text { supply and adverse } \\
\text { effect on domestic use. }\end{array}$ \\
\hline 5. & $\mathrm{Na} \mathrm{mg/l}$ & - & 200 & - & 200 & 2 & $\begin{array}{l}15 \text { to } \\
248\end{array}$ & -- \\
\hline 6 & $\mathrm{Cl} \mathrm{mg/l}$ & 200 & 600 & 250 & 1000 & 0 & $\begin{array}{l}14 \text { to } \\
322 \\
\end{array}$ & Salty Taste \\
\hline 7. & $\mathrm{SO} 4 \mathrm{mg} / \mathrm{l}$ & 200 & 400 & 150 & 400 & 1 & $\begin{array}{l}0.5 \text { to } \\
552 .\end{array}$ & Laxative effect. \\
\hline
\end{tabular}




\section{Conclusions:-}

$>\mathrm{Ca}-\mathrm{Mg}-\mathrm{HCO}_{3}$ type of water predominates in the study area during the Year 2016,

$>$ Though the suitability of water for irrigation is determined based on SAR, \% Na, RSC and Salinity hazard, it is only an empirical conclusion. In addition to water quality, other factors like soil type, crop type, crop

$>$ Pattern, frequency and recharge (rainfall), climate, etc. have an important role to play in determining the Suitability of water.

$>$ Water that is not suitable based on the above classification may be suitable in well-drained Soils.

D The suitability of water for irrigation is evaluated based on SAR, \% Na, RSC and salinity hazards. Most of

$>$ the samples in Study area fall in the suitable range for irrigation purpose either from SAR, \% Na or RSC

$>$ Values.

$>$ About $98 \%$ of the samples are grouped within $\mathrm{C}_{2} \mathrm{~S}_{1}$ and $\mathrm{C}_{3} \mathrm{~S}_{1}$ classes (Figures $10 \& 11$ ).

$>$ Most of the samples in study area fall in the suitable range for irrigation purpose from USSL diagram.

\section{Acknowledgement:-}

The author is grateful to the Department of studies in earth science, University of Mysore, Mysure for permission to prepare this paper.

\section{References:-}

1. Kelley, W. P.: Permissible composition and concentration of irrigation waters, Proc. ASCE, 1940, 66, 607.

2. Wilcox. L. V.: The quality water for irrigation use.US Dept. Agric. Bull., 1948, 1962, 40.

3. Handa, B. K.: Modified classification procedure for rating irrigation waters, Soil Sci., 1964, 98, 264-269.

4. Handa, B. K.: Modified Hill-piper diagram for presentation of water analysis data, Curr, Sci., 1965, 34, 131314

5. Hem, J. D.: Study and interpretation of the chemical characteristics of natural water. USGS Water Supply Paper, 1985, 2254, pp 117-120.

6. Zaporozee, A.: Graphical interpretation of water quality data, groundwater, 1972, 10, 32-43.

7. Maucha, R.: The graphic symbolization of the chemical composition of natural Waters, Hiderol, Kozlony, 1940, 29.

8. Stiff Jr., H. A.: The interpretation of chemical water analysis by means of patterns, J. Petrol. Technol., 1940, $3, \quad 15-16$.

9. Subramanian. Hydro geological studies of the coastal aquifers of Tiruchendur, Tamil Nadu. PhD thesis, Manonmanian sundaranar University, Thiruneveli, 1994, p-75.

10. Todd, D. K.: Groundwater Hydrology, Wiley, New York, 1980, 2nd edn. P-315.

11. Director of Census Operations. District Census Handling of Karnataka, Census of India, 1991.

12. Standard method for examination of water and wastewater, American Public Health Association, NW, DC 20036, 1994.

13. Piper, A. M.: A graphic procedure I the geo-chemical interpretation of water analysis, USGS Groundwater Note no, 1953, 12 .

14. Back, W.; Hanshaw, B. B.: Advances in hydroscience. In chemical Geohydrology, Academic Press, New York, 1965, Vol. 11, p-49.

15. Schroeder. H. A.: Relations between hardness of water and death rates from certain chronic and Degenerative diseases in the United States, J. Chron disease, 1960, 12:586- 591

16. Sawyer G. N.; McCarthy D. L.: Chemistry of sanitary Engineers, 2nd ed, McGraw Hill, New York, 1967, p518

17. Wicox, L. V.: Classification and use of irrigation waters, US Department of agriculture, Washington Dc, 1995, p-19.

18. Eaton, E. M.: Significance of carbonate in irrigation water. Soil Sci, 1950, 69, 12-133.

19. Kumaresan, M.; Riyazuddin: Major ion chemistry of environmental samples around Sub- urban of Chennai city, Curr, Sci, 2006, Vol. 91. No 12. 